\title{
Research on B2C E-commerce Marketing Strategies Using Jingdong Mall as an Example
}

\author{
Yuan-Yuan LAN ${ }^{1, a, ~}{ }^{*}$, Xiao-Ting QU ${ }^{1, b}$ \\ ${ }^{1}$ Beijing Jiaotong University, Beijing, China \\ a16113168@bjtu.edu.cn, bxtqu@bjtu.edu.cn
}

Keywords: B2C, E-commerce, Marketing strategies, Jingdong Mall.

\begin{abstract}
With the continuous development of Internet technology, e-commerce has been quietly forming, and it has become a new business model in China. The turnover of B2C e-commerce business has achieved an explosive growth in short period. There are two possible reasons why B2C e-commerce enterprises have been able to achieve great success. The first one is that they benefited from the policy environment support, and the second one is that their marketing strategies played an important role in promoting. This paper uses Jingdong Mall as an example to research B2C e-commerce marking strategies, which including product, price, place and promotion. Based on the SWOT analysis and questionnaire, this paper finds that there are some defects in Jingdong Mall's product quality, pricing, logistics time and new customer development. In order to improve marketing strategies, Jingdong Mall should improve product quality, implement low price strategy, optimize logistics system and improve promotion.
\end{abstract}

\section{Introduction}

With the rapid development of computer and Internet, e-commerce is gradually developing and quickly penetrated into social life. Now e-commerce has become an indispensable part of people's social life. The formation and development of E-commerce has not only promoted the information modernization, but also further promoted the development of economic globalization. E-commerce enterprises are divided into B2B, B2C, C2C, B2M and other types. Among these E-commerce enterprises, the well-known domestic B2C e-commerce enterprises are Taobao, Tmall, Jingdong, Amazon China, Suning, Gomeand so forth. These e-commerce enterprises have boosted the development of economic. According to some statistics, in the first half of 2016, China's e-commerce transactions reached 10.5 trillion yuan, which increased $37.6 \%$ than the same time's e-commerce transactions in 2015(China e-commerce research center (100EC.CN). "2016 (on) China e-commerce market data monitoring report". http://www.100ec.cn/zt/upload_data/B2B/EC.pdf, 2016.9.13.). Among that, B2C e-commerce transactions reached 2.64 trillion yuan, accounting for $25.14 \%$ of e-commerce transactions. To a large extent, the rapid development of B2C e-commerce enterprises benefited from rationally formulate and implement marketing strategies. So how do Domestic B2C enterprises' marketing strategies create hundreds of millions of transactions? Are there any marketing strategies limit those B2C enterprises to create higher turnover? And how to cover the shortages of those marketing strategies? In order to solve these questions, this paper take Jingdong Mall, the largest 3C enterprise in the domestic B2C market as an example, providing reference for domestic B2C enterprises to ameliorate their marketing strategies.

\section{Literature Review}

In the late 1940s, N.H. Borden(1948), American marketing expert, put forward the concept of "marketing mix" and defined 12 elements of marketing mix. As the basis of developing marketing strategies, "marketing mix" has been supplemented by later marketers. Rodgers McCarthy(1960) proposed a 4Ps marketing mix strategy, namely, product, price, promotion, and place. Taking the external environment's impact on enterprise development into account, in the mid-1980s, Philip Kotler added the public relationship and political power into 4Ps strategy, forming a 6Ps marketing 
mix strategy. In contrast to previous studies, Robert Lauteer born(1990) proposed a 4Cs theory, namely, consumer, cost, convenience, and communication. With the development of Internet e-commerce in the 1990s, the study of e-commerce marketing strategy is gradually increasing. Qiu Dongyang(2001) puts forward customer relationship management is the focus of future e-commerce marketing strategy[1]. Li Zhenhua and Wang Hanchen (2002) think that e-commerce as a new business model, its marketing strategy must be different from the traditional business model. Therefore, these two scholars added credit, change and core-competencies into the 4Cs,so that the 7Cs theory formed[2]. Liao Weihong and Zhou Shaohua(2012) believe that in order to make sure e-commerce enterprises obtain the success of marketing, these enterprises are supposed to establish an interactive communication mode with consumers[3].Li Weisheng and Jiang Xujun(2013) proposed that in the field of e-commerce, use limited cost to accurately deliver product and service information to the target consumer is not only helps improving customer loyalty, but also helps reducing companies costs, increasing profits, making consumer and enterprises achieve mutual benefit and win-win situation[4].

Above all these researches, we can safely draw a conclusion that e-commerce marketing strategy research is not only focusing on products, but also paying more attention to consumers to improve the marketing strategy. But it should also be noted that the current marketing strategy for e-commerce research is too general. Therefore, this paper takes Jingdong Mall as an example to analysis the B2C e-commerce enterprises marketing strategies, and proses some suggestions for e-commerce enterprises to ameliorate their marketing strategies.

\section{The Marketing Strategies of Jingdong Mall}

When the development of domestic e-commerce in a good situation, in January 2004, Jingdong entered the field of e-commerce, and opened Jingdong multimedia network. In June 2007, Jingdong multimedia network officially changed its name into Jingdong Mall. Jingdong Mall's market positioning is China's largest communications, computers, home appliances, digital products and online shopping mall, its target customers is network enthusiasts who have a stable income and active in online shopping[5]. As Jingdong Mall's current business scope expanded from the 3C products to daily necessities, cosmetics, books and other fields, its competitors also expanded from Gome, Suning to Taobao, Tmall, Amazon and some other online shopping platform. Among them, Gome and Suningis manly sell household appliances and electronics. Taobao and Tmall have abundant goods catalogue, and their commodity prices can adapt to different income types of consumer needs. As an overseas e-commerce enterprise, Amazon is able to cover plenty needs of domestic consumer's imported products' need. Jingdong Mall mainly use product, price, logistic, marketing publicity and some other marketing strategies to compete with numerous competitors and expand market share.

\section{Product Strategy}

As a professional digital products online shopping mall, Jingdong Mall's products including household appliances and electronics, computer accessories, mobile phones, network products, tens of thousands of direct marketing products. These varied products are all in low prices. Compared with the same type of other online shopping platform, Jingdong Mall'3C products are more diverse and high quality. In addition, there are daily necessities, food, books and other merchandise categories in Jingdong Mall, these commodities perfected Jingdong Mall's merchandise category. In addition, Jingdong Mall has set up a "Jingdong global purchase" platform, which has opened several national pavilion and regional pavilions, such as "Korea Pavilion", "Japan Pavilion", "US Pavilion", "Hong Kong Pavilion" and so forth (Jingdong, "Jingdong Enterprise Profile." https://www.jd.com/intro/about.aspx.). June 21, 2016, Jingdong Mall announced news that is Jingdogn Mall has achieved a depth of strategic cooperation with Wal-Mart. Jingdong Mall will have 1 hao store's assets, and the "Sam's Club" will be opened in the Jingdong Mall. This means that Jingdong Mall can also meet consumers' need of overseas products. 


\section{Price Strategy}

Jingdong Mall's commodity pricing seldom take peer price as reference, and the commodity price of Jingdong Mall is called "Jingdong price", which means that products' price is mainly in the purchase price of goods plus 5\% profit[6].Due to the lack of wholesale links, physical stores and brokers, Jingdong Mall respectively saves $20 \%$ of sales, $10 \%$ and $20 \%$. Consequently, Jingdong price is $10 \%-30 \%$ lower than manufacturer's guide price, and $10 \%-20 \%$ lower than Suning's and Gome's. In addition, the purchase method of imported products in Jingdong Mall is "overseas direct purchase", that is, reducing the traditional import channel nodes, the delivery of products will be reduced to "brand - Jingdong - consumers" to reduce the price of imported products[7]. Furthermore, Jingdong Mall also uses complementary product cross-pricing, bundling and other pricing methods. All these methods formed Jingdong unique pricing system, which further improves consumer satisfaction and loyalty[8].There is no doubt that, compared with traditional retail, Jingdong's reasonable goods will have greater competitiveness.

\section{Place Strategy}

Liu Qiangdong believes that, as a direct sales channel, the Internet can reduce or even eliminate the complex links of traditional channels so that commodities' distribution can be faster, and if they can relieve manufacturers of intermediate links, make commodities reach consumers more quickly, then Jingdong will be able to obtain more profits[9]. For that reason, different from other B2C enterprises, Jingdong Mall not only uses the outsourcing logistics, but also specifically creates a new logistics system. In addition, there are specialized colleges agent, who help solve the delivery problems. In the traditional retail industry, the products need to go through dealers, agents, retailers, and after 3-6 months they will reach consumers. While Jingdong rely on outsourcing logistics, own logistics system and college agents, it not only saves a lot of logistics time and logistics costs, but also greatly enhance the Jingdong brand awareness and reputation.

\section{Promotion Strategy}

\section{Advertisement}

Appropriate advertising can increase the number of the Web sites' accessing largely, promote corporate brand image, and raising the enterprises' wider profile, so as to achieve the purpose of expanding sales volume and increasing turnover. At the beginning of Jingdong Mall established, Jingdong adverted in major network platforms to improve the site traffic. In the commodity forums, bus stations, and other online offline place where people usually get together, Jingdong also use celebrity endorsements and other advertising means to enhance corporate brand awareness. Besides, Jingdong also implanted advertisement in the TV commercials. For example, in 2011, Jingdong Mall implanted advertisement in TV series "Men Bang". After achieving good results, Jingdong once again implanted advertisement in "Where Are We Going, Dad ", "The Greatest Love" and other reality shows. At the same time, Jingdong also usesmicroblog to enhance their visibility.

\section{Sales Promotion}

In terms of sales promotion, Jingdong Mall continuously organizes numerous "members of the special session", "old user welfare coupons ", "campus / business users special" and other activities. Annual June 18, Jingdong Mall will hold mid-celebration activities, commodities' price like computers, mobile phones, digital, and other daily supplies, will be lower than Jingdong price, the maximum decline can be 70\%[6]. In annual "double eleven" and "double twelve", Jingdong mall's numerous clothing, electronic products and other merchandise are on half sales. "Full reduction", "the whole point of snapping" and other activities on Jingdong Mall also plays an important impetus effect on higher sales. Through this series of promotional activities, Jingdong Mall brand awareness has been further improved, more potential consumers are gradually transformed into the actual consumers. 


\section{SWOT Analysis}

On May 4, 2015, the State Council issued "on the development of e-commerce, accelerate the development of new economic views". The Views pointed out that "To further develop e-commerce's effect on fostering new economic impetus, to create 'double engines', to achieve dual objectives and other effects", the Chinese government will "lower access threshold, reasonably cut down tax burden, increase financial support and maintain fair competition environment" to create a favorable environment for the development of e-commerce. On March 23, 2016, the General Office of the Ministry of Commerce issued "2016 e-commerce and information technology work points". The Notice clearly defined the work plan of "deepening the implementation of 'Internet + Circulation', speeding up e-commerce in rural areas, encouraging e-commerce to enter communities, promoting cross-border e-commerce development and strengthening e-commerce talent cultivation." At present, the domestic policy has created a favorable environment for the development of Jingdong Mall. But it's also indispensable for Jingdong Mal to tap their own advantages, clearly know deficiencies, and on this basis to further improve the marketing strategy. Therefore, this paper made a SWOT analysis for Jingdong Mall's external environment and internal resources.

Table 1: SWOT Analysis of Jingdong Mall Marketing Strategy

\begin{tabular}{|c|c|c|}
\hline External environment & Opportunity & Threat \\
\hline Internal resources & $\begin{array}{l}\text { National and local } \\
\text { government support } \\
\text { China's rapid economic } \\
\text { development and national income } \\
\text { increase } \\
\text { Increased number of Internet } \\
\text { users and online shoppers } \\
\text { from offline to online } \\
\text { fonsumption habits transfer }\end{array}$ & $\begin{array}{l}\text { Intense competition } \\
\text { C Customer's high bargaining } \\
\text { ability } \\
\text { Low profit } \\
\text { Imperfect laws and } \\
\text { regulations } \\
\text { Technical loopholes } \\
\text { Negative media coverage of } \\
\text { Jingdong }\end{array}$ \\
\hline Strengths & $S O$ & $S T$ \\
\hline $\begin{array}{l}\text { C Complete product } \\
\text { range } \\
\text { Advanced SCM } \\
\text { and ERP systems } \\
\bullet \text { Genuine low-cost } \\
\text { brand awareness } \\
\text { Excellent product } \\
\text { distribution capabilities } \\
\text { Excellent } \\
\text { management team } \\
\bullet \text { High cost control } \\
\text { ability }\end{array}$ & $\begin{array}{l}\text { Fully tap the market } \\
\text { resources, expand three or four } \\
\text { line cities } \\
\text { Increase brand marketing } \\
\text { efforts } \\
\text { logistics and distribution, shorten } \\
\text { the delivery time } \\
\text { Listing for more financing, } \\
\text { expand business } \\
\text { Maintain the advantages of } \\
\text { quality, price, service and so on, } \\
\text { create a good reputation }\end{array}$ & $\begin{array}{l}\text { Continuous segment market } \\
\text { to maintain the competitive } \\
\text { advantage } \\
\text { of Accelerate the construction } \\
\text { of distribution centers and } \\
\text { warehouses, reduce reliance on } \\
\text { logistics companies } \\
\text { Do well in crisis public } \\
\text { relationships, eliminate the } \\
\text { negative impact } \\
\text { co Do well in performance, } \\
\text { corporate culture and other } \\
\text { aspects of management }\end{array}$ \\
\hline Weakness & WO & $W T$ \\
\hline $\begin{array}{l}\text { Low product gross } \\
\text { margin, zero profit or } \\
\text { even deficit } \\
\text { Need to invest a lot } \\
\text { of money in logistics, R } \\
\& \quad \mathrm{D} \text { technology } \\
\text { upgrades and } \\
\text { expansion of product } \\
\text { categories } \\
\text { After-sales service } \\
\text { is not perfect } \\
\text { Internal staff } \\
\text { management difficult }\end{array}$ & $\begin{array}{l}\text { Increase } \mathrm{R} \& \mathrm{D} \text { efforts to } \\
\text { reduce logistics costs and product } \\
\text { costs } \\
0 \text { Self-built large warehouse to } \\
\text { ease the pressure on the stock } \\
0 \text { Looking for advanced } \\
\text { after-sale technical service, } \\
\text { improve the quality of after-sales } \\
\text { service }\end{array}$ & $\begin{array}{l}\text { - Improve after-sales service } \\
\text { as soon as possible } \\
\text { f Formulate affective } \\
\text { performance and incentive } \\
\text { systems, improve internal } \\
\text { management } \\
\text { As far as possible not } \\
\text { involve rivals professional fields }\end{array}$ \\
\hline
\end{tabular}

Source: obtained through the literature 


\section{Problems of Marketing Strategies}

Although in the past decade, Jingdong Mall sales is rising, and the rate of increase is still expanding. Through the preceding SWOT analysis, we can draw a conclusion that Jingdong Mall is facing some challenges, for instance, stiff competition, Customer's high bargaining ability, low profits, imperfect laws and regulations, Technical loopholes, negative media coverage and so forth. In order to further understand the weakness of Jingdong Mall's marketing strategy, the author has made a questionnaire survey. This survey mainly heard the opinions of online shippers. 250 questionnaires were distributed, 233 of them were valid questionnaires. The effective questionnaire rate was 93.20\%.The sex ratio of male to female was 4: 6; 88.38\% of the respondents were between 20-35 years old; and 50.62\% were college students, 36.93\% were working, individuals who don't have job were $12.45 \%$.Through this survey, we found that although Jingdong Mall's marketing strategy covers product, price, logistics and publicity, there are some problems, namely that uneven product quality, pricing risk, difficulty of guaranteeing logistics time, new customer development pressure and so on.

\section{Uneven Product Quality}

From the survey results, people who in the Jingdong Mall mainly buy computers, mobile phones, cameras and other digital products and accessories accounted for $67.96 \%$, who mainly buy daily necessities accounted for $34.47 \%$, who mainly buy TV set, refrigerator, washing machine and other Household electronics accounted for 25.73\%, who mainly buy shoes, hats, backpacks, clothing, accessories accounted for 23.79\%, who mainly buy cosmetics, books and other commodities accounted for $19.90 \%$. It is obvious that consumers of Jingdong Mall are more likely to buy 3C products and household appliances. Significantly, although $71.36 \%$ of the respondents use Jingdong Mall because of its goods quality assurance, $42.23 \%$ of the respondents they bought low-quality goods in Jingdong Mall, respondents who have never bought low quality goods only accounted for $57.77 \%$. It means that Jingdong Mall's product qualities are still need to improve.

\section{Pricing Risk}

In order to maintain a low-price advantage, Jingdong Mall's commodity price increase rate is $5 \%$. To a large extent, Jingdong Mall's low-price strategy is capable of attracting more consumers, but it also brings a big risk. After deducting logistics, labor, advertising, storage, after-sales service and other costs, the net profit is lower than others online shopping platform. In addition, the survey results show that people who use Jingdong Mall because of goods' low prices only accounted for 12.14\%.After comparison, we can find that lots of Jingdong Mall's goods can be found in Tmall and Taobao. Despite quality, a great deal of Tmall's and Taobao's goods are cheaper than Jingdong Mall's. Therefore, although Jingdong Mall has a "cheap" label, its "low price" label does not really play important role in attracting consumers.

\section{Difficulty in Guaranteeing Logistics Time}

At present, Jingdong Mall invests about 150 million in self-built logistics, although the self-built logistics system can play a part in lowering operating costs, shortening the supply time, ensuring the safety of the role of express delivery[10],the third-party outsourcing services also solves the logistics problems in second and third tier cities, the self-built logistics system delivery time cannot be fully guaranteed, and third-party logistics also cannot guarantee efficient high efficiency. According to the survey results, only $15.05 \%$ respondents were all receive the purchase of goods in the afternoon or the next day before $11: 00$ to, nearly $30 \%$ respondents receive the time was the second, third day or even later.

\section{New Customer Development Pressure}

In terms of new customer development, respondents who knew Jingdong Mall through the ad accounted for 39.33\%, respondents who knew Jingdong Mall through classmates, friends accounted for $25.94 \%$, respondents who knew Jingdong Mall through the search engine accounted for $18.41 \%$, 
respondents who knew Jingdong Mall through Jingdong's offline activities or other ways accounted for $16.32 \%$. 99\% of the respondents know Jingdong Mall, but only $41 \%$ of the respondents often use Jingdong Mall, 59\% of the respondents do not often do not even use Jingdong Mall or mainly use Taobao, Tmall and others online shopping platform. In addition, numerous potential consumers of the Jingdong have doubts on product quality, logistics time, after-sales service and so on. Jingdong also lack of comprehensive and detailed answers to these doubts, which led to Jingdong's new customer development become a big problem.

\section{Suggestions}

Considering these things that product quality, pricing, logistics, new customer development and other aspects will affect the long-term development of Jingdong Mall, this paper put forward some suggestions like enhance goods' quality, implement low-price strategy, optimize the logistics system, strengthen publicity.

\section{Improve Product Quality}

Product quality is an important aspect of successful marketing. If product quality cannot meet consumer expectations, that will reduce consumer loyalty. According to the survey results, although the reason why most consumers choose Jingdong Mall is product quality assurance, nearly half consumers bought low-quality goods in Jingdong Mall. Therefore, Jingdong Mall should strictly control the quality of both self-products and non-self-products, domestic products and imported products minimize even eliminate low-quality products appear in the mall. Increase the types of imported products, enhancing the quantity and quality of the mall can not only improve Jingdong Mall's visibility and reputation, the actual number of consumers and turnover can also increase.

\section{Implement Low-price Strategy}

Although Jingdong Mall mainly sell 3C products with the commitment of genuine and low-cost, we can still find that there are lots of cheaper and similar products in others online shopping platform. The other online shopping platform may have worse quality products, but it also reflects that the so-called Jingdong $5 \%$ gross margin pricing strategy is not really implemented. We mentioned that after deducting other costs, the net profit margin may not be guaranteed, but in the logistics, warehousing and other sectors, Jingdong Mall are able to reduce costs. Jingdong Mall is supposed to fully take the price of other online shopping platform into account, make the low-price strategy really play a part in attracting customers.

\section{Optimize the Logistics System}

Jingdong Mall must rely on advanced technology platform, integrated core resources, building a more efficient logistics system, to achieve the goal of cost reduction. In addition, Jingdong Mall need to build infrastructure, increase warehousing distribution center, reduce the cost of logistics to support Jingdong vertical and platform business[11].Jingdong Mall can expand storage area, improve its business process system, reduce the division of order, in order to reducing logistics. Via the improvement of infrastructure construction both at home and abroad, Jingdong Mall is able to reduce logistics costs, so as to cut commodity prices or increase profits. In addition, in order to reduce logistics costs, shorten logistics time and expand the distribution area, Jingdong Mall canspend more time and energy on $\mathrm{R} \& \mathrm{D}$, increase the usage of unmanned aerial vehicles, unmanned vehicles, unmanned warehouses, and implement intelligent logistics projects.

\section{Improve Promotion}

Jingdong Mall is supposed to emphasis the importance of new customer' development. The new customers are college students, office workers, housewives and so on.For network marketing platform, the search engine marketing has a great role in promoting the population of new customers. Through the search engine, Jingdong Mall's product information can be passed to potential customer, thereby the number of new customers can increase to a large extent. Compared 
to other online shopping platform, Jingdong Mall's resource investment in search engine marketing is not sufficient. In addition to use search engines to cultivate new customers, Jingdong Mall can use big data to improve the positive customers' loyalty. Via costumers' browse and consumption records, Jingdong Mall can divide customers into different types. Through e-mail, text messages or when customer log in the Jingdong Mall site, Jingdong Mall convey personalized information to the customers to improve user loyalty. In addition, Jingdong Mall can also adopt some other method like implanting advertisement into television series, etc. to increase brand awareness.

\section{References}

[1] Dong-Yang QIU. New Model of E-commerce Marketing-Customer Relationship Management [J]. Journal of Beijing Technology and Business University (Social Science), 2001, 16(5):26-29. (In Chinese)

[2] Zhen-Hua LI, Hu-Chen WANG. Research on the Marketing Combination Strategy of BtoC E-commerce [J]. Science of Science and Management of S. \& T., 2002, 23 (4): 66-69.(In Chinese)

[3] Wei-Hong LIAO, Shao-Hua ZHOU. Mobile E-commerce Interactive Marketing and Application Model [J]. Enterprise Economics, 2012 (3): 67-71.(In Chinese)

[4] Wei-Sheng LI, Xu-Jun JIANG. E-commerce Precision Marketing Strategy Research [J].Research and Development, 2013 (2): 46-49.(In Chinese)

[5] Si-Jie WU, Ang LI. Jingdong Mall Marketing Strategy Problems and Countermeasures [J]. Management, 2016 (13).(In Chinese)

[6] Yong REN. Explore on Jingdong Mall Marketing Status and Development Prospects [J]. Folk: Science Education, 2012 (12).(In Chinese)

[7] Jing Yan Internationalization from the beginning of imports [N]. International Business Daily, 2015-02-03 (A01).(In Chinese)

[8] Feng YANG. Analysis of Jingdong Mall E-commerce Marketing strategy [J]. Market Research, 2013 (9): 53-54.(In Chinese)

[9] Suan-yan YANG, Jingdong Mall's Special Model [J]. Chinese and foreign corporate culture, 2009 (6): 31-33.(In Chinese)

[10] Jing-Yi DU. Jingdong Mall Integrated Logistics System of Marketing [J]. Education and Teaching Forum, 2015 (38): 279-280.(In Chinese)

[11] Wen-Feng LU. Research on Jingdong Mall Competitive Strategy [D]. Shandong University, 2014.(In Chinese) 